Chirurgia (2020) 115: 89-94

No. 1, January - February

Copyright@ Celsius

http://dx.doi.org/10.21614/chirurgia.115.1.89

\title{
Bipolar en Bloc Resection - Is it the Future in Non-Muscle Invasive Bladder Cancer?
}

\author{
Bogdan Florin Geavlete ${ }^{1,2}$, Cosmin Victor Ene ${ }^{1,2}$, Georgiana Xenia Bălan ${ }^{1,2}$, Cătălin Andrei Bulai ${ }^{1,2}$, \\ Dragoș Adrian Georgescu ${ }^{1,2}$, Petrișor Aurelian Geavlete ${ }^{1,2}$
}

'Department of Urology, "St. John" Emergency Clinical Hospital, Bucharest, Romania

${ }^{2}$ Clinical Department No. 3, "Carol Davila" University of Medicine and Pharmacy, Bucharest, Romania

Corresponding author:

Petrisor Geavlete, MD, PhD

Professor Urology

"Carol Davila" University of Medicine and Pharmacy, Bucharest, Romania Department of Urology

"St. John" Clinical Hospital of

Emergency, Bucharest, Romania

E-mail: geavlete@gmail.com

\section{Rezumat \\ Rezecția bipolară en bloc - viitorul în tratamentul tumorilor vezicale non-infiltrative?}

Cancerul vezicii urinare este printre cele mai frecvente tumori urologice. În acest context, în ciuda tuturor progreselor tehnologice, rezecția transuretrală a vezicii urinare (TURV) continuă să reprezinte modalitatea de diagnostic şi tratament standard în tumorile vezicale non-invazive (NMIBT). Tehnica chirurgicală a rezecției tumorale bipolare en bloc ar putea fi realizată folosind electrodul cu buton emisferic cu plasmă în lichid de irigare salină sau se poate folosi fibra laser. Formațiunea malignă este treptat împinsă în sus şi separată de peretele vezicii urinare. Aspectul final al peretelui vezicii urinare dezvăluie fibrele musculare curate ale detrusorului, fără țesut malign rezidual. În ceea ce priveşte rezultatele, parametrii operatori sunt heterogeni în literatura de specialitate, din cauza diferitelor dispositive de rezecție utilizate. $\mathrm{Cu}$ toate acestea, există câteva puncte principale în toate studiile, cu privire la ratele de recurență mai mici, comparativ cu rezecția clasică şi, de asemenea, cele referitoare la buna calitate a mostrelor de rezecție. În concluzie, chiar dacă rezultatele generale sunt favorabile pentru rezecția în bloc, există deocamdată puține studii comparative multicentrice mari care să stabilească locul potrivit al metodei în armamentariumul urologic.

Cuvinte cheie: rezecție bipolară, en bloc, tumoră vezicală noninvazive 


\section{Abstract}

Bladder cancer is among the most common urological malignancies. In this context, despite of all the technological advancements, transurethral resection of bladder tumour (TURBT) continues to represent the gold-standard diagnostic and treatment in non-muscle invasive bladder tumours (NMIBTs). The surgical technique of en bloc bipolar tumour resection could be performed using the hemispherical shape plasma-button electrode and saline irrigation fluid or using the laser fiber. The malignant formation is gradually pushed up and separated from the bladder wall. The final aspect of the bladder wall reveals the clean muscular fibers of the detrusor layer, free of malignant tissue, irregularities or debris. Concerning the outcomes, the operative parameters are heterogenous in the literature, because of the different resection devices utilized. However, there are few main points where all the studies agreed, concerning the lower recurrence rates comparing with classical resection and also the good quality resection samples. In conclusion, even if the general outcomes are favourable for the en bloc resection, there is still a lack of large multicentric comparative trials which establish the right place of the method in the urological armamentarium.

Key words: bipolar resection, en bloc, non-muscle invasive bladder cancer

\section{Introduction}

Bladder cancer among the most common urological malignancies. Similarly, with another neoplastic pathologies, a complete resection is essential to achieve a good prognosis (1).

In this context, despite of all the technological advancements, transurethral resection of bladder tumour (TURBT) continues to represent the gold-standard diagnostic and treatment in non-muscle invasive bladder tumours (NMIBTs) according to the EAU Guidelines. However, a complete resection can be achieved by either fractioned or en-bloc resection (2). En-bloc resection could be performed using monopolar or bipolar current, Thulium-YAG or Holmium-YAG laser being feasible in selected exophytic tumours, with an important advantage because it provides high quality resected specimens with the presence of detrusor muscle in $96-100 \%$ of cases (3-5), as is specified in the 2019 EAU Guidelines. Reaching an accurate diagnosis, especially in the pathologic stage $(\mathrm{p} T)$, is important to choose appropriate treatment strategies in these patients. Furthermore, an accurate histopathological diagnosis leads to reduction of overall treatment costs, because an unnecessary second
TUR procedure or adjuvant intra-vesical therapy is avoided (6). The damage of resected tissue is quite impossible to be avoided in traditional TUR, the ideal resection method preserving the resection mass, especially in solid tumours. That is why the en bloc resection appeared to be a valid option from 20 years ago because of a very good preserving of pathological specimen (7). The only debatable subject is linked to the tumour dimension suitable for resection. Hurle et al. suggested that patients with a single tumor with diameter $<30 \mathrm{~mm}$ and/or those with $<4$ lesions are eligible for en-bloc resection (4), while Sureka et al. excluded tumors over $40 \mathrm{~mm}$ in diameter (8). Lodde et al suggested that a tumour diameter over $25 \mathrm{~mm}$ could represent a contraindication for en-bloc resection (9). The effectiveness of $\mathrm{Ho}$ :YAG or Tm:YAG laser treatment was also proved by many studies (10), because of the advantages of en-bloc laser resection which consists in the absence of the obturator reflex, minimal intraoperative bleeding, reduced hospitalization period, and lower complications, as compared to conventional TUR $(2,11)$. However, laser resection is inferior to electrical resection in terms of availability and medical economics.

Last but not least, in univariate or multi- 
variate analysis performed to assess the impact of potential prognostic factors on recurrence-free survival, it was observed that neither age nor the number of days between primary and second en bloc resection were independent predictors of recurrence, the only predictor of recurrence being the tumor grade $(12,13)$.

\section{Operatory Technique}

The surgical technique of en bloc bipolar tumour resection could be performed using the hemispherical shape plasma-button electrode (Fig. 1) and saline irrigation fluid, using the loop (Fig. 2) or using the laser fiber. The malignant formation is step by step separated from the bladder wall (Fig. 3). It could be performed for achieving that aspect, both the bipolar plasma vaporization and the mechanical detachment using the "button" shape electrode or the loop (Fig. 4). It should be mentioned in the end, that only by taking specimens from the tumour bed implantation area using the standard semicircular resection loop, canconfirms the accuracy of the malignant tissue ablation process by en bloc resection. Tumour bed plasma button coagulation constitutes the last stage of the procedure (Fig. 5). The final aspect of the bladder wall reveals the clean muscular fibers of the detrusor layer, free of malignant tissue, irregularities or debris (Fig. 6) (14).

To perform en-bloc resection of large, malignant bladder tumors, various modified methods and new devices could be used. Naselli et al. retrieved tumors with diameters $\leq 45 \mathrm{~mm}$ using Collins loop and laparoscopic forceps (15). Meanwhile, Frische et al. performed en-bloc resection of tumors under $75 \mathrm{~mm}$ in diameter, using a water jet dissector and needle knife for transurethral dissection (16). A study evaluated the combined use of electrical en-bloc resection of the tumor (E-EBRT) and TUR to treat patients with NMIBC. Although E-EBRT was performed for single tumor masses $\leq 3 \mathrm{~cm}$ and for those $\mathrm{BCs}$ with $\leq 4$ lesions, the en-bloc resection was limited to tumors with $\leq 3$ lesions, and those with diameters $\geq 4 \mathrm{~cm}$ was

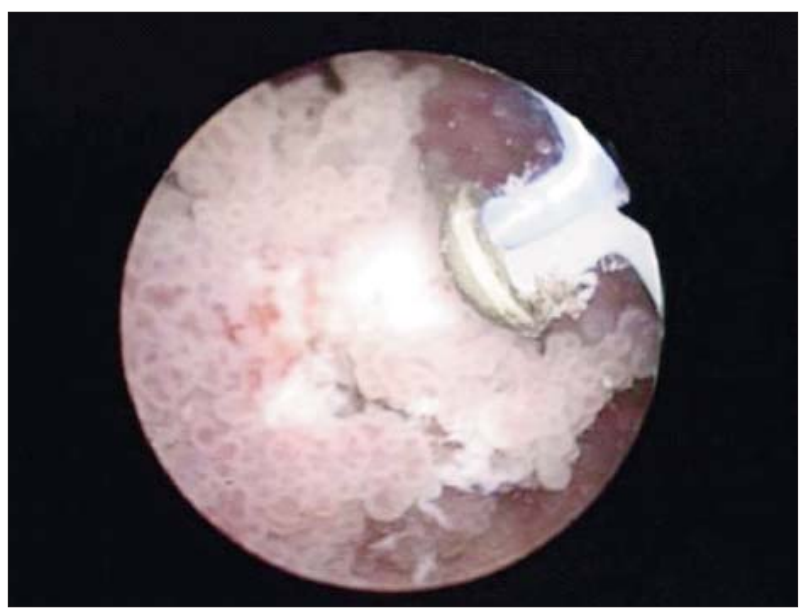

Figure 1. En- bloc plasma button vaporization - bladder tumour eligible for this procedure

removed via TUR (17).

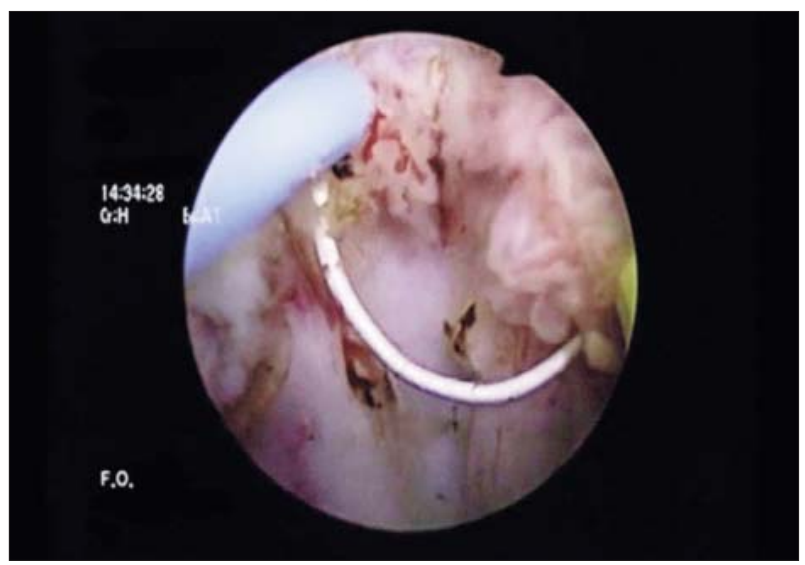

Figure 2. En bloc resection - bladder tumour

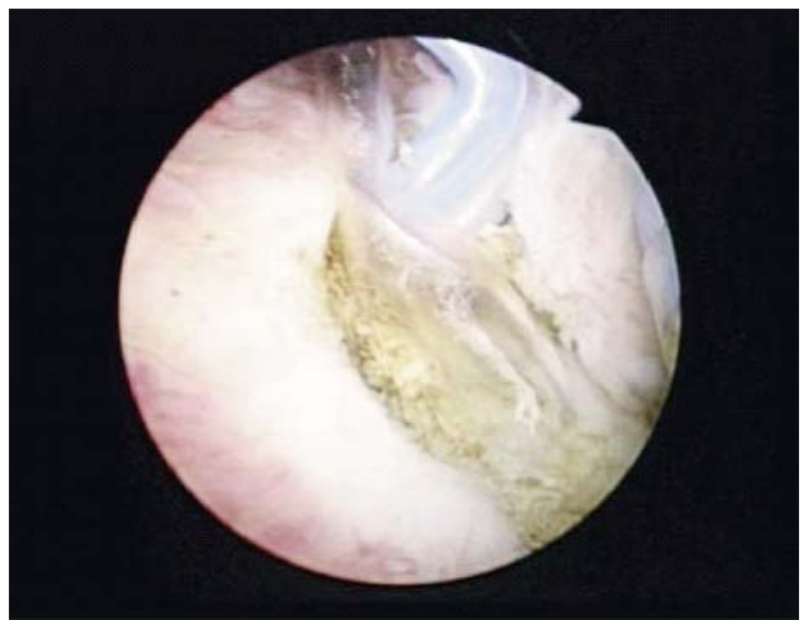

Figure 3. En bloc resection - pushing up the bladder wall 


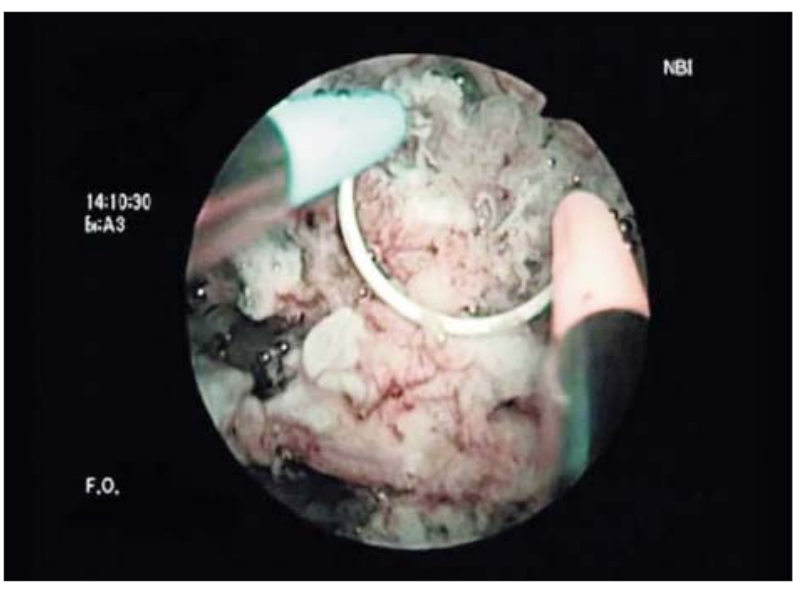

Figure 4. En bloc detachment with the loop in NBI mode

\section{General outcomes}

According to some studies, en bloc resection had the main advantage of a shorter operation time (22 minutes (18) versus 46 minutes (19)), in conventional TURBT, because the principle of the method consists in the resection of the tumor base and subsequently, in detaching the lesion in one piece. Also, in another study, Hayashida et al. showed an operatory time of $16.9 \mathrm{~min}$ for en bloc resection versus 17.3 TURBT for tumors of up to three $\mathrm{cm}$ (6) for the resection of one tumor. D'souza reported for en bloc resection performed with Ho laser, for an average number of tumors of 2.5, an operatory time of $58.2 \mathrm{~min}$ (10), while for Green light enucleation, for an average number of 1.76 tumors, the operatory time was of $21.46 \mathrm{~min}$ (20) and for Thulium-YAG, that was significantly higher, of $56.5 \mathrm{~min}$, for an average tumor number of 1.8 (21). A new study about

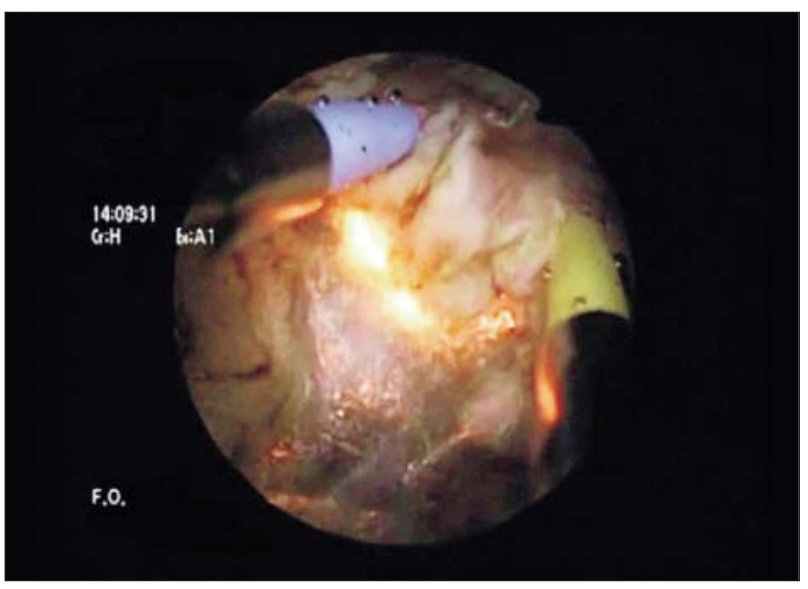

Figure 5. En bloc detachment - free muscular layers - bipolar loop

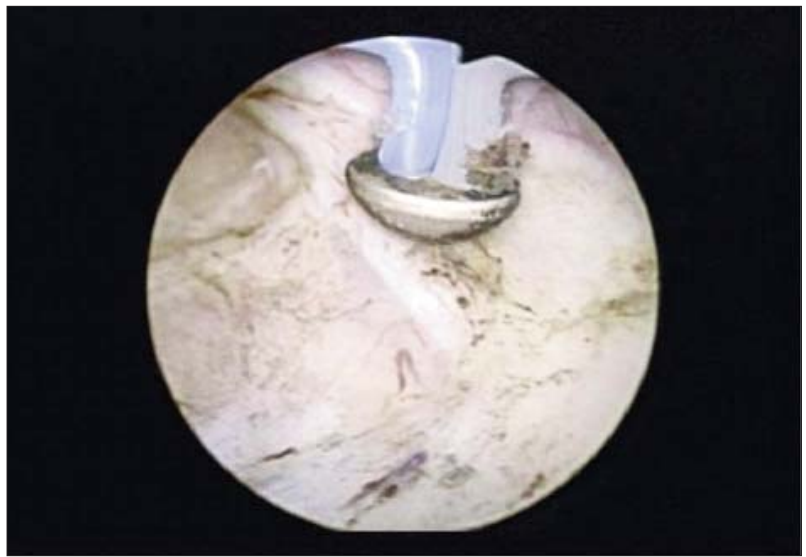

Figure 6. Plasma coagulation of the tumour bed

en bloc bipolar resection with plasma button showed similar outcomes concerning the operatory time of average $35 \mathrm{~min}$ (12) (Table 1).

When compared to the classical TURBT, the bipolar en bloc resection patients benefited from significantly reduced catheterization

Table 1. The operatory time using different devices for en bloc resection in NMIBC

\begin{tabular}{llcc}
\hline Study & Device used & $\begin{array}{c}\text { Operatory time } \\
\text { (en bloc resection) }\end{array}$ & $\begin{array}{c}\text { Average number } \\
\text { of tumors }\end{array}$ \\
\hline Zhong C. et al & HoLBRT & $22 \mathrm{~min}$ & $\mathrm{NA}$ \\
\hline Hayashida Y. et al. & TURBT & $16.9 \mathrm{~min}$ & 1 \\
\hline D'Souza N. et al. & Ho-Laser & $58.2 \mathrm{~min}$ & 2.5 \\
\hline Chen J. et al. & Green light Laser & $21.46 \mathrm{~min}$ & 1.76 \\
\hline Chen X. et al. & Thulium-YAG & $56.5 \mathrm{~min}$ & 1.8222 \\
\hline Zhang J. et al. & Bi-TURBT & $35 \mathrm{~min}$ & 1.43 \\
\hline
\end{tabular}


period (1.4 days (11) or 2 days in another study (12) versus 4.2 days (19)) and hospital stay (1.5 days (22) or 3 days in another study (12) versus 4.27 days (23)). All in all, there are other studies that showed a similar period of catheterization in the case of en bloc resection, of 4.2 days in comparison with TURBT where the period was 3.7 days, without a statistical significance difference between the groups (6). Also, the complication rate was similar in the en bloc resection group versus TURBT according to Clavien-Dindo classification (6). However, the most common complications for TURBT remains bleeding and obturator nerve reflex, while for en-bloc TURBT, no uncontrollable bleeding, perforation, or other severe complications were observed (12). Hurle et al., realized in a multicentre observational study that both, en-bloc primary and re-resection procedures were feasible, safe, associated with low complication rates (4).

Concerning the pathologically confirmed tumor stage, the range of literature data presents a relatively wide variation for $\mathrm{pTa}$ (37.5-54\% (9)), as well as for pT1 (46-62.5\% (24)) NMIBT stage.

Even more, during the long-term follow-up (30-40 months), en bloc resection had a lower recurrence rate by comparison to the standard procedure (28.6\% versus $62.5 \%$ ) (8). The recurrence rate at the first follow-up cystoscopy (RRFF-C at 3 months) was $3.85 \%$ (three patients) (25). A very recent multicentre study realized by Hurle et al. on 78 patients with NMIBC to which was performed an en bloc reresection after the initial en bloc resection revealed only five residual cancers: one patient with pTaG3 (1.28\%), and four having pTis (5.13\%) (25). There are also many studies either with bipolar or laser en bloc resection that mentioned presence of the detrusor muscle in all the samples, without being infiltrated by tumor cells, that representing a significant advantage of the method $(12,25)$.

\section{Conclusions}

Nowadays en bloc resection could be realized in many ways: monopolar, bipolar or using different models of lasers. The outcomes are similar with classical resection methods, but there is still a lack of large multicentric comparative trials which establish the right place of the method in the urological armamentarium.

\section{Conflict of Interest}

The authors have no disclosures.

\section{References}

1. Brausi M, Collette L, Kurth $\mathrm{K}$, van der Meijden AP, Oosterlinck W, Witjes JA, et al. Variability in the recurrence rate at first follow-up cystoscopy after TUR in stage Ta T1 transitional cell carcinoma of the bladder: a combined analysis of seven EORTC studies. Eur Urol. 2002;41(5):523-31.

2. Kramer MW, Altieri V, Hurle R, Lusuardi L, Merseburger AS, Rassweiler J, et al. Current Evidence of Transurethral En-bloc Resection of Nonmuscle Invasive Bladder Cancer. Eur Urol Focus. 2017;3(6):567-576

3. Kramer MW, Rassweiler JJ, Klein J, Martov A, Baykov N, Lusuardi $\mathrm{L}$, et al. En bloc resection of urothelium carcinoma of the bladder (EBRUC): a European multicenter study to compare safety, efficacy, and outcome of laser and electrical en bloc transurethral resection of bladder tumor. World J Urol. 2015;33(12):1937-43.

4. Hurle R, Lazzeri M, Colombo P, Buffi N, Morenghi E, Peschechera R, et al. "En Bloc" Resection of Nonmuscle Invasive Bladder Cancer: A Prospective Single center Study. Urology. 2016;90:126- 30.

5. Migliari R, Buffardi A, Ghabin H. Thulium Laser Endoscopic En Bloc Enucleation of Nonmuscle-Invasive Bladder Cancer. J Endourol. 2015;29(11):1258-62.

6. Hayashida Y, Miyata Y, Matsuo T, Ohba K, Sakai H, Taba M, et al. A pilot study to assess the safety and usefulness of combined transurethral endoscopic mucosal resection and en-bloc resection for non-muscle invasive bladder cancer. BMC Urol. 2019;24: 19(1):56.

7. Kawada T, Ebihara K, Suzuki T, Imai K, Yamanaka H. A new technique for transurethral resection of bladder tumors: rotational tumor resection using a new arched electrode. J Urol. 1997; 157(6):2225-6.

8. Sureka SK, Agarwal V, Agnihotri S, Kapoor R, Srivastava A, Mandhani A. Is en-bloc transurethral resection of bladder tumor for non-muscle invasive bladder carcinoma better than conventional technique in terms of recurrence and progression?: a prospective study. Indian J Urol. 2014;30(2):144-9.

9. Lodde M, Lusuardi L, Palermo S, Signorello D, Maier K, Hohenfellner R, Pycha A. En bloc transurethral resection of bladder tumors: use and limits. Urology. 2003;62(6):1089-91.

10. D'souza N, Verma A. Holmium laser transurethral resection of bladder tumor: our experience. Urol Ann. 2016;8(4):439.

11. Zhu Y, Jiang $X$, Zhang J, Chen W, Shi B, Xu Z. Safety and efficacy of holmium laser resection for primary nonmuscle-invasive bladder cancer versus transurethral electroresection: single-center experience. Urology. 2008;72(3):608-12.

12. Zhang J, Wang L, Mao S, Liu M, Zhang W, Zhang Z, et al. Transurethral en bloc resection with bipolar button electrode for non-muscle invasive bladder cancer. Int Urol Nephrol. 2018;50(4): 619-623.

13. Liang $H$, Yang $T$, Wu K, He D, Fan J. En bloc resection improves the identification of muscularis mucosae in non-muscle invasive bladder cancer. World J Urol. 2019: in print. 
14. Balan GX, Geavlete PA, Georgescu DA, Ene CV, Bulai CA, Paunescu $M A$, et al. Bipolar en bloc tumor resection versus standard monopolar TURBT - which is the best way to go in non-invasive bladder cancer? Rom J Morphol Embryol. 2018;59(3):773-780.

15. Naselli A, Introini C, Germinale F, Spina B, Puppo P. En bloc transurethral resection of bladder lesions: a trick to retrieve specimens up to $4.5 \mathrm{~cm}$. BJU Int. 2012;109(6):960-3.

16. Fritsche HM, Otto W, Eder F, Hofstädter F, Denzinger S, Chaussy $\mathrm{CG}$, et al. Water-jet-aided transurethral dissection of urothelial carcinoma: a prospective clinical study. J Endourol. 2011;25(10): 1599-603.

17. Clavien PA, Barkun J, de Oliveira ML, Vauthey JN, Dindo D, Schulick RD, et al. The Clavien-Dindo classification of surgical complications: five-year experience. Ann Surg. 2009;250(2): 187-96.

18. Zhong C, Guo S, Tang Y, Xia S. Clinical observation on 2 micron laser for non-muscle-invasive bladder tumor treatment: singlecenter experience. World J Urol. 2010;28(2):157-161.

19. Liu H, Wu J, Xue S, Zhang Q, Ruan Y, Sun X, Xia S. Comparison of the safety and efficacy of conventional monopolar and 2-micron laser transurethral resection in the management of multiple nonmuscle-invasive bladder cancer. J Int Med Res. 2013;41(4): 984-992.

20. Chen J, Zhao Y, Wang S, Jin X, Sun P, Zhang L, et al. Green-light laser en bloc resection for primary non-muscle-invasive bladder tumor versus transurethral electroresection: a prospective, nonrandomized two-center trial with 36-month follow-up. Lasers Surg Med. 2016; 48(9):859-865.

21. Chen X, Liao J, Chen L, Qiu S, Mo C, Mao X, et al. En bloc transurethral resection with 2-micron continuous-wave laser for primary non-muscle-invasive bladder cancer: a randomized controlled trial. World J Urol. 2015;33(7):989-95.

22. Abotaleb AA, Kandeel WS, Elmohamady B, Noureldin YA, El-Shaer W, Sebaey A. Bipolar plasma kinetic enucleation of non-muscle invasive bladder cancer: initial experience with a novel technique. Arab J Urol. 2017;15(4):355-359.

23. Xishuang S, Deyong Y, Xiangyu C, Tao J, Quanlin L, Hongwei G, et al. Comparing the safety and efficiency of conventional monopolar, plasmakinetic, and holmium laser transurethral resection of primary non-muscle invasive bladder cancer. J Endourol, 2010, 24(1):69-73.

24. Zhang KY, Xing JC, Li W, Wu Z, Chen B, Bai DY. A novel transurethral resection technique for superficial bladder tumor: retrograde en bloc resection. World J Surg Oncol. 2017;15(1):125.

25. Hurle R, Casale P, Lazzeri M, Paciotti M, Saita A, Colombo P, et al. En bloc re-resection of high-risk NMIBC after en bloc resection: results of a multicenter observational study. World J Urol 2019 May 21(Online ahead of print). 